\title{
Batam Tourism Application Based on Android Mobile
}

\author{
Afdhol Dzikri ${ }^{1}$, Tri Ramadani ${ }^{2}$ \\ 1,2 Teknik Multimedia Jaringan, Politeknik Negeri Batam \\ afdhol@polibatam.ac.id ${ }^{1}$, ramadani@polibatam.ac.id $^{2}$
}

\begin{tabular}{l} 
Article Info \\
\hline Article history: \\
Received 2018-04-01 \\
Revised 2018-06-21 \\
Accepted 2018-09-10 \\
\hline
\end{tabular}

Keyword:

Batam Destination, Android, Location Based Service, MySQL.

\begin{abstract}
The existence of a destination becomes one aspect of Batam City as a destination for domestic and foreign tourists. Destination places in the form of hotels, tourist destinations, sports, shopping, places of worship and tourism. This tourist destination in the metropolitan city has an important role as the heart of the city community activities. In this study discusses the use of the internet as a medium to find Batam Destination information combined by using an Android-based mobile application. The method used is Location Based Service (LBS) according to the location of the user to get the location and route to the destination of the destination in a quick and easy way. The application design phase uses some storage assistance in MySQL as a database on the webserver. This destination search application has the main feature of being able to find the closest destination location according to the user's location at that time by utilizing GPS technology. After the application is produced it will be tested with Alpha Test. The result of this research is a geographic information system application for Destinations Batam. The results of system testing indicate that this information system is feasible and can be used.
\end{abstract}

\section{INTRODUCTION}

Batam is one of the cities located in Riau Islands province which has an area of around $1,570.35 \mathrm{~km} 2$ and consists of 12 Subdistricts namely Batam City, Nongsa, Bengkong, Batu Ampar, Sekupang, Belakang Padang, Bulang, Sagulung, Galang, Lubuk Baja, Sungai Beduk, Batu Aji. Although Batam City has a very rapid development among city cities in Indonesia, but Batam City also has a historical place that is still maintained, one of which is Vietnam Village. However, historical sites in Batam City are still very rarely visited by visitors, this is due to a lack of recognition of historical sites in Batam City. It is unfortunate if the historic place was left unnoticed by the people of Batam City and from outside Batam City [14].

One of the historical attractions in Batam City is Kampung Vietnam which is a historical tourist spot located on Galang Island, formerly this place was a refuge for Vietnamese citizens due to the civil war that took place in Vietnam in the $1970 \mathrm{~s}$, therefore a a breakthrough that can provide an introduction to historic sites in Batam City, not only tells but also can show the location of historic places on maps that can be accessed via smartphone so that it helps the community or visitors to find historical sites in Batam City and visit them [9].

This application is applied to the Android smartphone as well as interactive learning by adding quiz features that are expected to train the memory of users in knowing the historical places in Batam City.

\section{RELATED WORK}

\section{A. Batam History}

History is something that has happened in the past and is compiled based on the legacy of an event. The importance of history is like the expression of Bung Karno in his speech on August 17, 1966 [4] "never once leave history", because there are many things from history that we can learn.

One of the historical sites in Batam City is the Barelang Bridge, designed by Mr. BJ Habibie in 1992 and completed in 1998 and divided into 6 bridges, and Barelang itself stands for Batam Rempang Galang and is used as an icon of Batam City by the Batam City Government. Not only is Barelang 
Bridge a place that has a history in Batam City, but there are several other places that have history such as Vietnam Village, Limas Cut House, King Isa Family Cemetery, Perigi Air Raja, Brick Chimney Brick Work Factory Raja Ali Kelana, The Temenggung Family Tomb Complex Abdul Jamal.

\section{B. Android Studio}

Android Studio is a new development environment released by Google for the Android operating system and is already very well known at this time. Android Studio is also a development of Eclipse, therefore Android Studio has very complete features [13].

This study uses Android Studio because it has features that are very complete and can meet the needs of making an application about the history that exists in Batam City.

\section{ANALYSIS AND DESIGN}

\section{A. General System Description}

The following is an application system design for the introduction of location-based Batam city history.

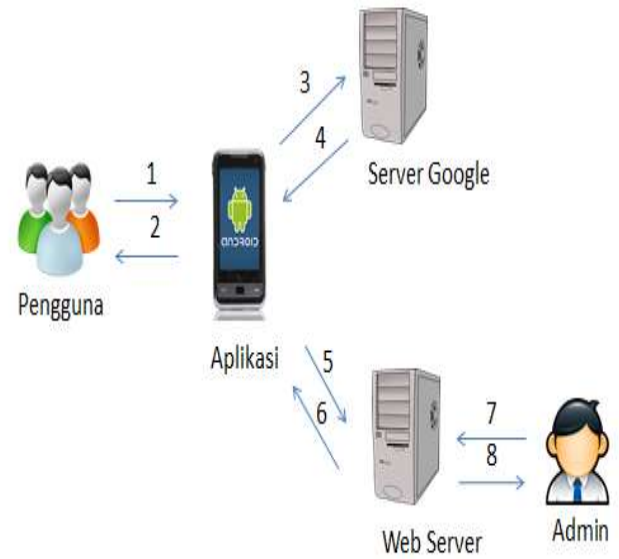

Figure 1.General system description

System design steps when a user uses the application:

1. Users search for information in the form of a brief explanation, location (including route) and answer quizzes about historical sites in Batam City.

2. The application displays information in the form of a brief explanation, location (including route), as well as quizzes (quizzes, quiz points, quiz winners) about historical sites in Batam City.

3. The application requests data on the location of historic locations in Batam City.

4. Google servers send data on the location of historic locations in Batam City.
5. The application asks for data in the form of short explanations and quizzes (quizzes, quiz points, quiz winners) about historical sites in Batam City.

Web Server sends data in the form of short explanations and quizzes (quizzes, points

1. Quizzes, quiz winners) about historical sites in Batam City.

2. Admin manages data about location descriptions and quizzes (quizzes, quiz points, quiz winners) around historical sites in Batam City.

3. The web server displays information in the form of a brief description of the location and quiz (quiz, quiz points, quiz winner) about historical sites in the city of Batam.

\section{B. Entity Relationship Diagram}

Entity Relationship Diagrams are designed to have relationships between tables and attributes that are owned by each entity and its relationships.

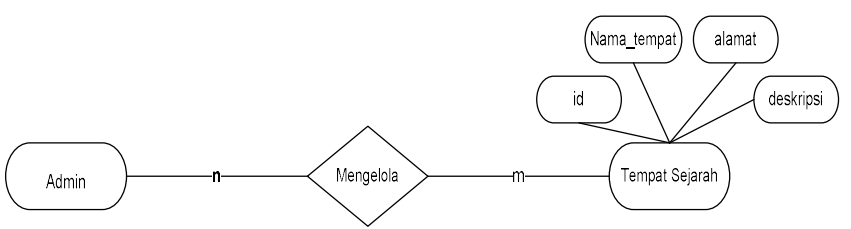

Figure 2.Entity Relationship Diagram

Database design when managing historical place data by admin. Admin can manage many historical places, where history has attributes id, place_name, address, and description.

\section{IMPLEMENTATION AND TESTING}

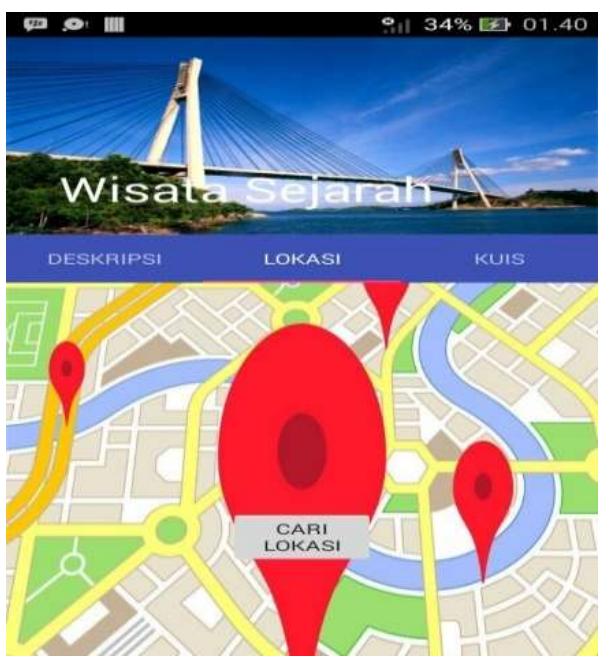

Figure 3. Main Menu 
Figure 3 is a display of the main menu that will appear when the application starts on the run. The main menu function is executed by creating a function in public Fragment getItem (int position) which contains an action where each content will move according to the selected menu.

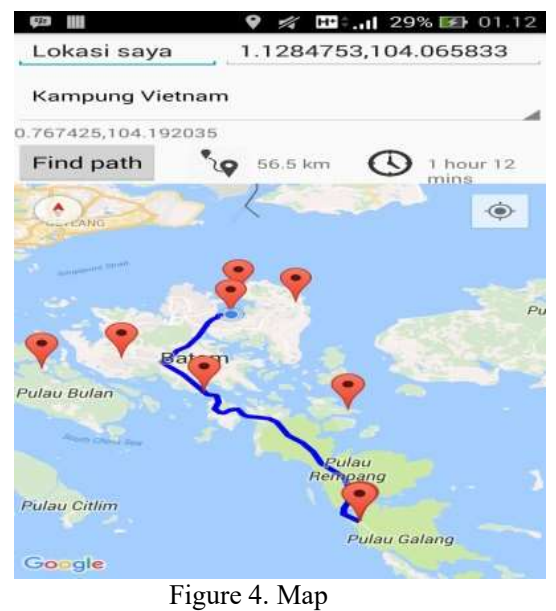

Figure 4 is a map view that will appear after selecting the location map menu. The location map menu function is executed by creating a protected void onCreate (Bundle savedInstanceState) function that contains an action where the map will be placed on a fragment on the map menu.

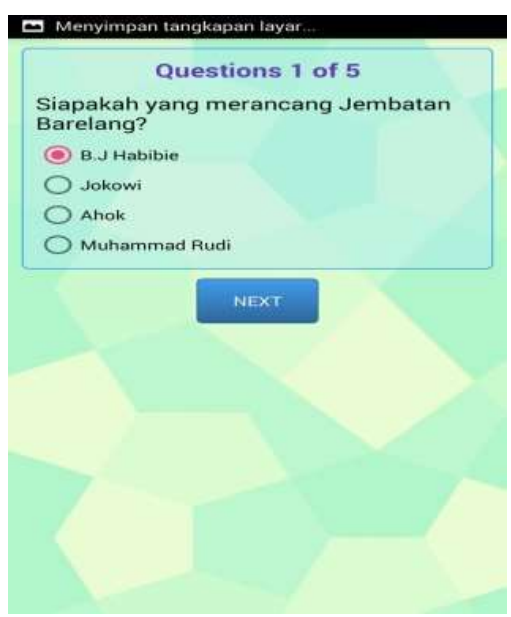

Figure 5. Quiz Menu

Figure 5 is a quiz display that will appear after selecting the quiz menu. The quiz menu function is run by creating a public void init () function that contains an action where the quiz will be displayed along with the answer choices provided. The quiz can be continued after selecting one answer then pressing the next button.

Figure 6 is a display of quiz points that will appear after completing the quiz. The quiz point menu function is run by creating a function that contains an action where the quiz points will be displayed in the form of a star symbol in accordance with the acquisition of the obtained value. Then the answer key will be visible after selecting the view answer button

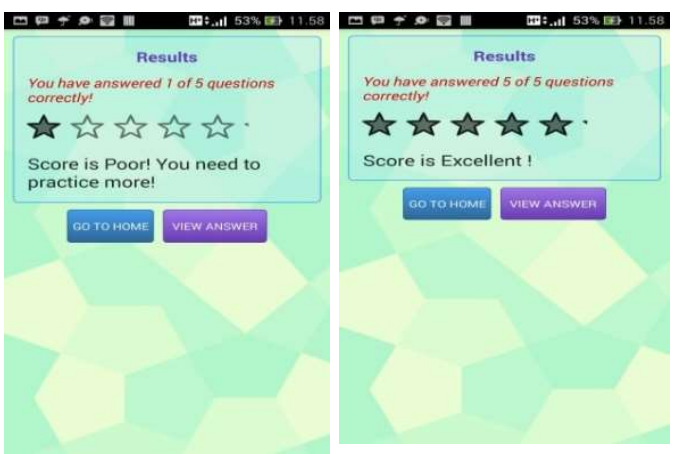

Figure 6. Quiz poin

Figure 7 is a display of the answer key that will appear after completing the quiz and getting points. The answer key menu function is executed by creating a function that contains an action where the answer key will be displayed in text form. The answer that was previously chosen will also be displayed by retrieving data from the database.

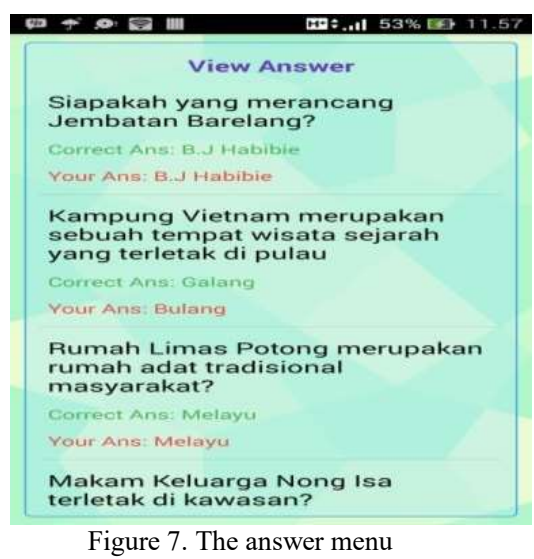

Figure 8 is a Display Description that contains a list of places of history that will be displayed if you select the description menu. Description Menu Function contains an action where historical information is displayed in the form of images, names and addresses.

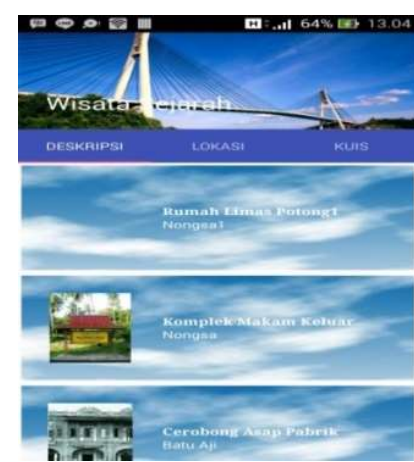

Figure 8. Description menu 
Figure 9 Menu is a Detail Display Description that will be displayed after selecting one of the historical places. Description Menu Function contains an action where historical place information is displayed in detail in the form of images, names, and addresses.

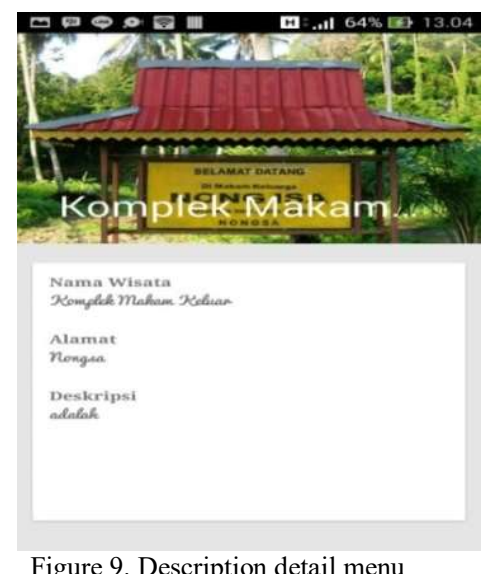

Figure 9. Description detail menu

Figure 10 is the admin management view. Admin can manage historical place data such as adding, displaying, changing, and deleting.

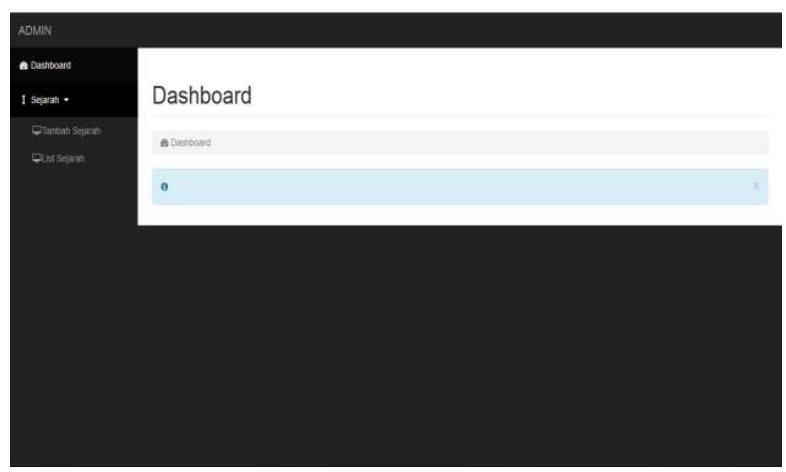

Figure 10. Admin management menu

\section{CONCLUSION}

The conclusion of this research is:

1. Android Based Search Application can display the distribution of historical places in Batam City.

2. Application can calculate distance, time and path from location to destination

3. Android Based Search Application that can also display information in the form of a brief description of historical sites in Batam City

For future development to be better, the following are suggested:

1. The GUI display is still very simple in the admin and user view, for example in coloring.

2. Management of quizzes.

\section{REFERENCE}

[1] Charibaldi, N., 2010, Solusi Pemrograman Java (Dilengkapi Contoh Soal dan Penyelesaian), Yogyakarta: Pyramida.

[2] Ciptaningtyas, H. T., \& Kuswardayan, I., 2014, Aplikasi Pembelajaran Sejarah Secara Interaktif Berbasis Lokasi. In Seminar Nasional Teknologi Terapan (SNTT) 2014

[3] Dewi, T. P., 2003, Pengembangan pariwisata sejarah di pulau galang Â batam (studi kasus rencana strategis pengembangan wisata sejarah bekas kamp pengungsi Vietnam dan wisata lainnya di pulau galang yang berwawasan lingkungan).

[4] Kurniawan, S., 2011, JAS MERAH. Retrieved Februari 25, 2014, from Kompasiana:http://sejarah.kompasiana.com2011/09/15/jas-merah395781.html

[5] Kuswardayan, I., 2010. Palawa. Retrieved Februari 25, 2014 from GameEdukasi :http://www.gameedukasi.com/2010/12/palawa-gamesejarah-palagan-ambarawa/

[6] Mulyani, E. S., \& Kusuma, W. 2012. Aplikasi Location Based Service (LBS) Taman Mini Indonesia Indah (TMII) Berbasis Android. Jurnal Program S1 Sistem Informasi Universitas Gunadarma.

[7] Nadjmi, N.P. B., \& Mada, F. T. U. G. 2011. Pulau Batam Sebagai Kawasan Destinasi Wisata Terpadu di Kepulauan Riau.

[8] Nugroho, A., 2009, Rekayasa Perangkat Lunak Menggunakan UML dan Java. Penerbit Andi.

[9] Nurhayati, N., 2016, Analisis Investasi Sektor Pariwisata Oleh Pemerintah Daerah Kota Batam Tahun 2014. DIMENSI, 5(2).

[10] Nurnawati, E. K., \& Muryanto, J. 2014. Aplikasi Mobile Berbasis Lokasi Untuk Penyedia Lokasi Layanan Kesehatan di Yogyakarta. In Seminar Nasional Aplikasi Sains \& Teknologi(SNAST) 2014.

[11] Pemko, Batam 2014, Oktober 2., "Wisata Sejarah Kota Batam". Retrieved from Website Pemko Batam: http://skpd.batamkota.go.id/pariwisata/objek-wisata-batam/wisatasejarah/.

[12] Prahasta, E., 2005, Sistem Informasi Geografis: Aplikasi Pemrograman MapInfo Pengembangan Aplikasi SIG dengan Menggunakan Borland Delphi, Ms. Visual Basic \& MapBasic. Bandung: Informatika.

[13] Prio, B. A., 2016, Aplikasi Berbasis Android Pencarian Atm Mandiri Terdekat Menggunakan Algoritma Dijkstra. Skripsi, Fakultas Ilmu Komputer.

[14] Purwanti, A., 2013, Penataan dan Peningkatan Infrastruktur Sebagai Salah Satu Strategi Komuniaksi Dinas Pariwisata dan Kebudayaan Kota Batam Dalam Visit Batam. Jurnal Charta Humanika, 1.

[15] Putra, C.A., 2017. "Pengantar Google Maps". Retrieved from 4 Januari 2017 website: . http://www.candra.web.id/pengantar-googlemaps-api/.

[16] Raharjo, G., 2011, Aplikasi penunjuk posisi menggunakan google maps dan GPS hardware berbasis Android (Doctoral dissertation, STMIK AKAKOM Yogyakarta).

[17] Rosiska, E., 2016, Perancangan Dan Implementasi Wisata Batam Berbasis Android. Telcomatics, 1(1).

[18] Kurniawan, D. E. (2017). Simulasi Perhitungan Tarif Pada Pemandu Wisata Berbasis Perangkat Bergerak. CESS (Journal of Computer Engineering, System and Science), 2(1), 12-16.

[19] Kurniawan, D. E. (2016). Pemetaan Jalur Transportasi Bus Umum Kota Batam Menggunakan QuantumGIS dan Geoserver. Jurnal Teknologi dan Sistem Informasi, 2(2), 1-8.

[20] Kurniawan, D. E., \& Amanda, S. T. (2017). Pemilihan Rumah Menggunakan Metode Weight Product dengan Visualisasi Lokasi Objek. KLIK\&58; Kumpulan jurnaL Ilmu Komputer, 4(1), 102-111.

[21] Z. Agha, A. Triwinarko, and B. Hamuna, "Pemetaan Industri di Kota Batam Menggunakan Mobile GIS Berbasis Android", JAIC, vol. 1, no. 1, pp. 1-4, Jul. 2017.

[22] Safaat, N., 2015, Android: Pemrograman Aplikasi Mobile Smartphone dan Tablet PC Berbasis Android, Revisi Kedua.

[23] Santoso, M. P., 2011, Pembuatan Mobile Application Peta Wisata Berbasis Platform Android di Kabupaten Sragen (Doctoral dissertation, Universitas Muhammadiyah Surakarta). 